\title{
Library Cooperation In Kansas City
}

\author{
BY ROBERT B. DOWNS
}

The potentialities of regional library development and cooperation-under the impetus of federal subsidies, foundation grants, the mounting pressures of student enrollments, the research needs of scholars and research workers, and inflated prices-are being explored in various areas of the United States. A recent example is the activities of the Kansas City Regional Council for Higher Education, established in 1962 to encourage and promote cooperative planning in and near Kansas City.

From the outset, the council recognized the fact that libraries are an essential element in the educational programs of colleges and universities. Prior to adoption of any plans for the improvement of present library resources, however, the council requested and received a grant from the Fund for the Advancement of Education for a study of existing conditions. Specifically, it proposed to examine library holdings and policies in councilaffiliated institutions; to draft recommendations for cooperation among the council libraries and between these libraries and other institutions in the Kansas City area; and to investigate the possibility of creating a central depository library.

Approximately ten thousand full-time and six thousand part-time students are currently enrolled in the fourteen institutions comprising the council membership, distributed among seven four-year, coeducational, Protestant church-related colleges, three Catholic colleges (two for men and one for women), a city-supported junior college, an art institute offering a bachelor of arts degree, a gradu-
Dr. Downs is Dean of Library Administration in the University of Illinois.

ate theological seminary, and a campus of the University of Missouri (formerly the University of Kansas City). Three of the fourteen institutions are in Kansas, the remainder in Missouri, the most remote about one hundred and ten miles from Kansas City.

The first steps in the process of examination were the application of certain quantitative standards to the group of libraries: total number of volumes, number of volumes in relation to enrollment, rate of growth of book collections, book expenditures, periodical subscriptions, overall financial support, size of staffs, and building facilities.

The ACRL Standards for College Libraries specify a minimum of fifty thousand selected volumes for an institution enrolling not in excess of six hundred students, and ten thousand volumes for every additional two hundred students. Applying these criteria to the general four-year colleges belonging to the council revealed that only five of the ten institutions met the two recommended minima.

A similar criterion is the rate of growth of book collections. A steady increase is of course essential to the maintenance of any good college library; otherwise, its holdings become obsolescent. No fixed standards are recognized, but an inspection of statistics for top-ranked four-year college libraries in various parts of the country shows an average annual growth rate of some five thousand volumes and an annual book budget of not less than 
$\$ 25,000$. Only one of the libraries in the Kansas City council group met these two criteria.

The strength of periodical holdings is another useful criterion in measuring a library's collections. Extensive files of general, scholarly, and specialized journals are fundamental in an institution of higher education. Quality rather than quantity is emphasized in the ACRL Standards, but some quantitative guidance is furnished by standard lists and by figures from leading college libraries. A sampling of the latter brings out the fact that current periodical subscriptions number from six hundred to twelve hundred titles. It is reasonable, therefore, to expect that a good four-year college library will receive no less than five hundred wellselected journals if it is to provide a fairly adequate representation of the immense range of periodical literature available. Only two Kansas City council libraries presently meet the suggested minimum figure.

Directly related to the matter of collection development and other aspects of library operation, of course, is financial support. A standard of 5 per cent of an institution's total educational budget is widely - though not universally - accepted as a proper proportion for the maintenance of strong library service. The ratios of support among the libraries associated with the Kansas City council are generally low. Eight of the fourteen institutions spend less than the recommended figure of 5 per cent for their libraries. Of the ten four-year colleges, four exceeded the minimum standard.

It should be observed that despite the evident desire to develop libraries to serve as centers for their educational programs, the colleges' own serious financial limitations and problems frequently inhibit the growth of library resources and facilities. Until there is marked improvement in the financial condition of the parent institutions, the libraries are unlikely to fare much better than at present, except as they may be fortunate enough to receive support from other sources.

With few exceptions, library space is tight in the council institutions, and in several instances extremely crowded, $e$.g., in the University of Missouri at Kansas City and Missouri Valley College. Four colleges, however, are in the fortunate position of having adequate new buildings or buildings in progress.

Another matter directly related to the libraries' service potentialities is size of staffs. The ACRL Standard specifies a minimum of three professional librarians in a college library - a chief librarian and staff members responsible for readers' services and technical services-and additions as student enrollment expands. There should also be at least an equivalent number of clerical staff members. Among the fourteen institutions in the Kansas City council, eight have a single professional librarian each and are similarly short on clerical workers. In the main, they must rely on student assistants to fill the gap.

The combined resources of the fourteen council libraries total some eight hundred fifty-five thousand volumes. Beyond these institutions and in the immediate area, however, is a group of libraries whose holdings are far more extensive and of basic importance in any program of over-all development and cooperation. Of first significance are the Kansas City public library and the Linda Hall library, with collections in excess of one million, two hundred thousand volumes. The public library's strong divisions of business and technology, social sciences, literature, travel and biography, art and music, and local, state, and regional history are admirably supplemented by Linda Hall's extraordinary resources for the pure and applied sciences. Both the public library and Linda Hall are already experiencing a heavy strain on their collections and services caused by the influx of college and university students, and the demands on them are growing by leaps and bounds.

Also to be taken into account are the 
facilities of the Nelson art gallery library in Kansas City, the Harry S. Truman library at Independence, a few miles east of Kansas City, and a considerable number of special libraries in the immediate area. Somewhat peripheral at this stage, but potentially of great value to the council libraries, are the resources of the University of Kansas at Lawrence, forty miles to the west, and the University of Missouri at Columbia, 130 miles to the east. Each possesses a million-volume-plus library and notable specialized collections in various fields.

Thus, there are within a radius of 130 miles from Kansas City library resources approximating five million volumes.

The extent of library use has a direct bearing on the need for expanded book collections and for cooperation among libraries. Statistics of circulation, as librarians are aware, represent only a fraction of actual library use. The nonrecorded use of books in libraries may be three to nine times as great as the formal circulation figures. Similarly, student use of libraries in the Kansas City area, notably in the public library and Linda Hall library, is not reflected in circulation records.

Total figures for volumes borrowed and loaned among the council libraries are unimpressive. On the other hand, these are primarily undergraduate institutions, and interlibrary loans are limited by common practice to faculty members and graduate students. All except one of the libraries borrow more than they lend.

The individuals who should be, and often are, most familiar with the strengths and weaknesses of college libraries are the faculty members who must depend upon them to support ongoing educational programs. To obtain the views of the several faculties in the council institutions, therefore, all members of professorial rank were asked a series of questions. The replies were revealing.

About one-third of the respondents judged their libraries to be inadequate over all. Among the most frequently mentioned deficiencies were the lack of current and retrospective files of periodicals, poor coverage of subject fields in the curricular offerings, limited collections of reference works, and failure to maintain collections up-to-date. Basic reserve books were insufficient to meet the needs of large classes. One consequence is a trend requiring students to purchase paperback books, instead of depending upon multiple library copies. It was frequently apparent that professors were shaping their teaching methods to fit library materials available, though they expressed a preference for different approaches.

A query on the relationship of library resources to graduate study was chiefly applicable to the University of Missouri at Kansas City, as none of the colleges in the council's membership offer graduate programs. The matter is of concern, however, to younger faculty members working toward advanced degrees in universities elsewhere, who find themselves handicapped by the lack of standard books and journals on their own campuses. Weak library facilities are also likely to restrict the background reading of the best undergraduate students preparing themselves for graduate study.

By no means unique to the Kansas City council institutions, but a widespread practice among them, is the introduction of new courses without previous provision of library resources. Faculty members eager to initiate new curricular offerings fail to recognize the need for coordinating these programs with the library administration. Thus, lacking prior information, the library staff is unprepared for the demands suddenly made upon it in hitherto undeveloped fields. Again, in such situations, there is often reliance upon paperback books to fill the void.

A debate is going on among the Kansas City council institutions, as in college libraries elsewhere, on the extent to which faculty research should be supported. Because of the specialized nature of much 
individual faculty investigation and writing, it is generally recognized that the average college library can offer only partial support. Nevertheless, if the library fails to provide specialized resources up to the limit of its ability, faculty members will be unable to keep abreast of advances in their areas, will be discouraged from undertaking to write on scholarly subjects, and the younger, more ambitious instructors will be inclined to look for greener pastures. Institutional investments in books and journals mainly of interest to the teaching staff contribute to faculty morale, prevent intellectual stagnation, and indirectly, at least, substantially benefit the students.

On the basis of visits to the individual libraries, conferences with administrators, the sampling of faculty opinion, and various factual data, a series of recommendations for action was presented to the Kansas City council. The proposals offered for consideration were grouped under seven headings.

1. Collection development. Define, recognize, and encourage fields of specialization among the libraries. Continue to develop the Kansas City public library and the Linda Hall library as bibliographical centers for the region. Where desirable and possible, arrange for other libraries in the council group to be designated as selective depositories for United States government publications. Through cooperative purchasing or by agreed division of projects among the libraries, bring into the region valuable research materials covered by current microreproduction programs. Check appropriate standard bibliographies of books, reference works, and periodicals against the holdings of individual libraries, and fill in lacunae.

2. Cooperative storage. Transfer from the council libraries for storage in the Kansas City public library (except scientific and technical publications to Linda Hall) collections of older federal and state documents, uncataloged material for which no local need is apparent, and sel- dom used or obsolescent books and journal files. Maintain the transferred collections at the Kansas City public library in a separate, well organized unit available to all member libraries.

3. Bibliographic access. Complete the regional union list of serials, in process, to include all council libraries; from the data supplied therein, consolidate broken files and add important missing titles. Develop a selective regional union catalog, located in the Kansas City public library, recording pre-1900 imprints, materials in special collections, and any expensive, unusual titles acquired by council libraries.

4. Expediting use. Use telephones more extensively in speeding requests for interlibrary loans and information. For the transportation of interlibrary loans, equipment, and people among the campuses, acquire and operate on a regular schedule a station wagon or similar vehicle, or, as an alternative, depend on quick commercial bus or truck service, using "jiffy" bags for books. Arrange to provide microfilm or Xerox copies of material at cost from a central photographic service, aiming at twenty-four hour service.

5. Centralized processing. Explore the potential advantages, financial and otherwise, of a central nonprofit acquisition agency to buy books, arrange periodical subscriptions, and contract for binding. Similarly, consider the establishment of a central cataloging service, where a few expert catalogers could carry on a more efficient and productive operation than under the present decentralized system. Also desirable is a central nonprofit photographic laboratory to serve the council libraries; such facilities are already available in the Kansas City public library and Linda Hall library.

6. Finances. Vigorous continuing efforts need to be made to strengthen the financial support of individual libraries, especially in those institutions where library expenditures are less than 5 per cent of total educational expenditures. A 
major building program is needed to solve the serious space problems of a majority of the council libraries. The Kansas City public library and the Linda Hall library ought to be compensated financially for the heavy load being placed on them by the college and university students and faculties of the region.

7. Regional library authority. To enable the Kansas City public library and the Linda Hall library to develop their collections further and to provide qualified professional staff for operating a cooperative organization, establish a regional library authority. The regional authority would be charged with such functions as providing specialized and scholarly library services to the students, scholars, research workers, and any other serious investigators of the area; acquiring important books, periodicals, and other materials in all subject fields of interest; planning cooperative storage and improving bibliographical and physical access to the region's resources; providing advisory service to college libraries; sponsoring centralized processing and other measures that may contribute to more effective regional library service; and finding means of financing a broad program of library service and cooperation.

The plight of the private college in the United States (all except one of the Kan- sas City council members, it should be noted, are private institutions) is well illustrated by those in the Kansas City area. Now, as in the past, such colleges are performing an exceedingly valuable educational function. In many respects, their contribution to American higher education has been, and is, unique. In a rapidly changing national scene, however, the less richly endowed colleges are struggling for survival. They are faced with inflationary costs, placed at a competitive disadvantage in being forced to charge tuition rates almost prohibitively high in relation to publicly supported institutions, experiencing increasing difficulties in recruiting qualified faculty members, and unable to meet the best standards for the maintenance of such facilities as libraries and laboratories. Yet, with rapidly expanding enrollments and the exploding demands immediately ahead for admission to institutions of higher education, there has never been a period in our history when the good private college was more indispensable. To enable it to survive, and to maintain high standards and ideals, is likely to require governmental, foundation, and other forms of subsidization, and active cooperation with its neighbors in such enterprises as those visualized by the Kansas City Regional Council for Higher Education.

\section{CRL Indexes}

BEGINNING with Volume XV (1954) the index for each volume of $C R L$ has appeared in the January issue of the next volume. In 1964 $C R L$ is going back to the pattern which was followed for the first fourteen volumes; the index for the current volume will be printed in the center of the last issue of this volume, November 1964. It is hoped that this arrangement can continue for succeeding volumes.

This volume also completes a five-year cycle, for which cumulative indexes are prepared. Plans are now underway for publication of the cumulative index for volumes XXI-XXV sometime during the fall of 1965; distribution arrangements will be announced after Midwinter Meeting, 1965. 